\title{
Pre-event water contributions and streamwater residence times in different land use settings of the transboundary mesoscale Lužická Nisa catchment
}

\author{
Martin Šanda $^{1 *}$, Pavlína Sedlmaierová ${ }^{1}$, Tomáš Vitvar ${ }^{1}$, Christina Seidler ${ }^{2}$, Matthias Kändler ${ }^{2}$, Jakub \\ Jankovec $^{1}$, Alena Kulasová ${ }^{3}$, František Paška ${ }^{4}$ \\ ${ }^{1}$ Department of Irrigation, Drainage and Landscape Engineering, Faculty of Civil Engineering, Czech Technical University in Prague, \\ Thákurova 7, 16629 Prague 6, Czech Republic. \\ 2 Technische Universität Dresden, International Institute Zittau, Markt 23, 02763 Zittau, Germany. \\ ${ }^{3}$ T. G. Masaryk Water Research Institute, Podbabská 30, Prague 6, Czech Republic. \\ ${ }^{4}$ Crop Research Institute, Drnovská 507, Prague 6, Czech Republic. \\ * Corresponding author. Tel.: +420 22435 3739. Fax: +420 233324861. E-mail: martin.sanda@fsv.cvut.cz
}

\begin{abstract}
The objective of the study was to evaluate the spatial distribution of peakflow pre-event water contributions and streamwater residence times with emphasis on land use patterns in 38 subcatchments within the $687 \mathrm{~km}^{2}$ large mesoscale transboundary catchment Lužická Nisa. Mean residence times between 8 and 27 months and portions of preevent water between 10 and $97 \%$ on a storm event peakflow were determined, using ${ }^{18} \mathrm{O}$ data in precipitation and streamwater from a weekly monitoring of nearly two years. Only a small tracer variation buffering effect of the lowland tributaries on the main stem was observed, indicating the dominant impact on the mountainous headwaters on the runoff generation. Longest mean streamwater residence times of 27 months were identified in the nearly natural headwaters of the Jizera Mountains, revealing no ambiguous correlation between the catchment area and altitude and the mean residence time of streamwater. Land use control on the pre-event water portions were determined for three land use categories with percentage of urban areas from 0 to $10 \%, 10$ to $20 \%$ and more than $20 \%$. The fraction of pre-event water in the first category decreases from $97 \%$ to $65 \%$ with the increasing percentage of forest from $76 \%$ to $100 \%$, revealing that forests may provide only a limited infiltration of precipitation due to leaf interception and soil water use for transpiration. Fractions of pre-event water of $39-87 \%$ in the second (agricultural catchments) and of 10-35\% in the third (urbanized catchments) category increase with percentage of non-urban areas.
\end{abstract}

Keywords: ${ }^{18} \mathrm{O}$ isotope; Stormflow event; Peak pre-event contributions; Mean residence time; Land use.

\section{INTRODUCTION}

Tracing of hydrological processes in nested mesoscale catchments at scales between 100 and $1000 \mathrm{~km}^{2}$ (Uhlenbrook et al., 2004) is often hampered by differences and inconsistency of data between small and large scales. Upscaling of abundant process knowledge from small headwater catchments has been more widely performed to mesoscale catchments around $100 \mathrm{~km}^{2}$ of area, for example in Switzerland (Köplin et al., 2014) and UK (Tetzlaff et al., 2007).

The role of groundwater contributions to streams and streamwater residence times in catchment hydrology has been widely acknowledged over the past decades. Several studies have addressed the role of soil cover (Capell et al., 2012), topography and geometry (McGuire et al., 2005, Soulsby et al., 2010) of nested smaller subcatchments in water pathways and residence times, often adopting tracer approaches. Hydrological processes at the mesoscale are also often related to land use, which becomes an important parameter in runoff modelling (Isik et al., 2013; Montzka et al., 2008; Niehoff et al., 2002). However, recent reviews of the assessment of subsurface water contributions to streams and streamwater residence times (Klaus and McDonnell, 2013; McDonnell et al., 2010) revealed a principal need for a better understanding of the spatial distribution of their patterns across catchment scales. Linkages between pre-event water contributions, residence times and landscape settings often show opposite results, explained by specific catchment conditions (Klaus and McDonnell, 2013). Despite of abundant knowledge of mixing processes at headwater scales, little is known about the transfer of the typical ap- proaches (two-component mixing, sine-wave estimation of residence times) from small experimental catchments to more complex scales. Although new tracer analytical techniques facilitate a better in-situ temporal monitoring at smaller scales (e.g. Holko et al., 2011), the spatial distribution of the runoff generation parameters and their interpretation remain a challenge.

More work on the understanding of hydrological processes is particularly needed in catchments of size towards $1000 \mathrm{~km}^{2}$. Successful examples of a consistent isotopic assessment of nested streamwaters of mesoscale and large-scale catchments in the contiguous US (Dutton et al., 2005; Kendall and Coplen, 2001) reveal important hydrological patterns and links to climatic and geological settings that are often hidden at headwater or large scale. Tracing of hydrological processes in the mesoscale catchments between 500 and $1000 \mathrm{~km}^{2}$ has been often performed through surveys of isotopic or chemical tracers along the stream courses. It has been typically linked to hydrological (Popescu et al., 2008), geochemical or pollution patterns (Markovics et al., 2010; Pardo et al., 2004), whereas the largescale surveys have addressed geochemical, climatic or anthropogenic patterns (Pawellek et al., 2002), often resulting from channel deviations and water abstractions (Herczeg and Leaney, 2011).

This paper summarizes the nearly 2-years long period of hydrometeorological and isotopic monitoring in the Lužická Nisa catchment and its 38 subcatchments with the objective to evaluate magnitude and distribution of pre-stormflow-event water portion and streamwater residence times linked to the altitude, catchment area and land use patterns. Although several studies 
have addressed the increasing occurrence and magnitude of floods in the Lužická Nisa catchment in pan-European (Alfieri et al., 2014), and regional (Bissolli et al., 2011) context, little is known on the hydrological processes that cause the floods and pollution fluxes. These topics have been addressed dominantly at point or small headwater catchment scale (Kändler and Seidler, 2009; Šanda et al. 2014). Hydrological evaluation of the catchment has been largely missing. A synthesis over the transboundary mesoscale catchment was hampered by data inconsistency. Except for the small headwater Uhlírská in the Jizera Mountains (Šanda et al., 2014), this is the first study to employ environmental isotopic data in the larger Lužická Nisa mesoscale catchment.

\section{Study site}

The mesoscale catchment of the Lužická Nisa (Lausitzer Neisse in German) river from the Jizera Mountains in the Czech Republic to the German lowlands in the vicinity of Zittau is characterized by many land use types and a large variety of hydrological and hydrochemical patterns. The differences are mostly related to the interaction of the forested-mountainous Jizera Mountains in the Lužická Nisa subcatchment, the agricultural-lowland Zittau basin in the subcatchment Mandava (Mandau in German) and the major cities of Liberec and Jablonec n.N. Names of the rivers in this paper match the language of the country of their spring.

The Lužická Nisa catchment (Fig. 1) covers parts of Czech Republic, Germany and Poland and reaches from the headwaters region in the Jizera, Lužice and Zittau Mountains down to the gauge station on the Lužická Nisa in Zittau (German/Polish border). The tributaries above Zittau include small rivers originating in the Jizera Mountains (e.g. Bílá Nisa, Harcovský potok, Černá Nisa, Jeřice) and along the Ještěd Ridge (Františkovský potok). The most prominent tributary, the Mandava
River, originates in the north of Bohemian-Saxonian Swiss sandstone area, flows southeast-east across the region of Upper Lusatia north of Zittau Mountains, and joins the Lužická Nisa in Zittau. Important tributaries of the Mandava are Lužnička (Lausur in German) and Landwasser in Germany. The catchment $\left(687 \mathrm{~km}^{2}\right)$ divides into Czech $\left(476 \mathrm{~km}^{2}\right)$, German (205 $\left.\mathrm{km}^{2}\right)$ and Polish $\left(6 \mathrm{~km}^{2}\right)$ parts, with altitudes between $886 \mathrm{~m}$ a.s.l. in the Jizera Mountains (Olivetská hora summit) and $229 \mathrm{~m}$ a.s.l. at the gauge station Zittau.

Water is transfered from outside of the Lužická Nisa catchment for the drinking water supply of the metropolitan area of Liberec and Jablonec n. N. and related settlements forming agglomeration of about 200 thousand inhabitants. Both water reservoirs of Josefův Důl on the Kamenice River and Souš on the Černá Desná River are located in the Labe river regional catchment. They collect water from the headwaters of the highest locations of the Czech part of the Jizera Mountains reaching above $1000 \mathrm{~m}$ a.s.l. This results in additional volumes and hydrochemical signatures in the Lužická Nisa catchment (Farský, 1992).

The Lužická Nisa catchment belongs to the temperate climate zone in the transient region between maritime and continental conditions, with precipitation maxima in July and August (Pohle et al., 2015). Heavy rains occur frequently during spring and summer. Long term annual precipitation amount varies between approximately $1400 \mathrm{~mm} \cdot \mathrm{a}^{-1}$ in higher altitudes of the mountains and $640 \mathrm{~mm} \cdot \mathrm{a}^{-1}$ in the lowlands. The Jizera Mountains are characterized by long lasting snow cover of up to 160 days/year. Mean annual temperature varies between $8^{\circ} \mathrm{C}$ in the lowlands and $5^{\circ} \mathrm{C}$ in the mountains (Šanda et al., 2014).

The complex geological structure of the catchment is dominated by granites and granodiorites in the Jizera Mountains (Klomínský, 1969), sandstones in the Zittau Mountains and granite with basaltic and phonolitic hilltops in the western part.

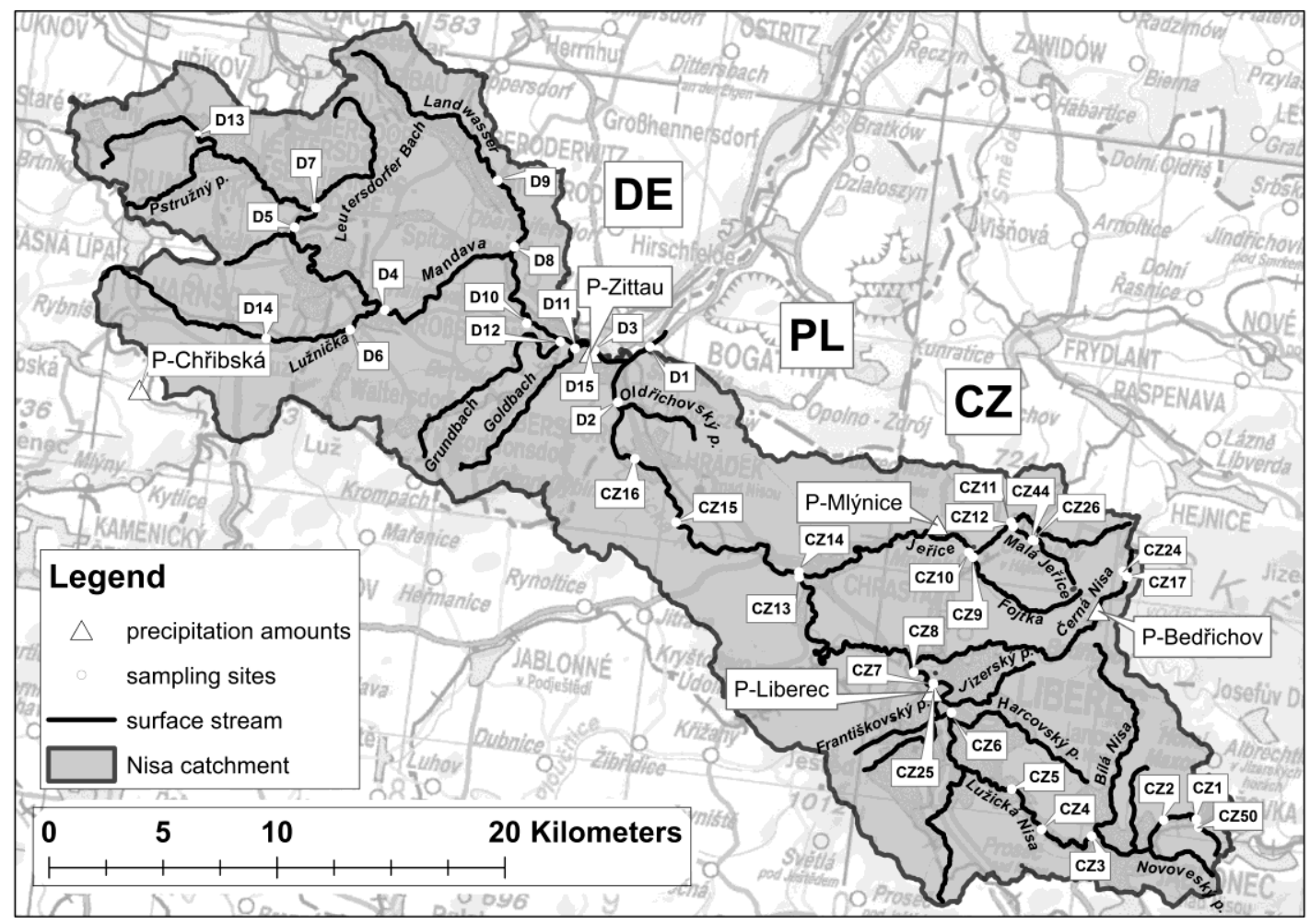

Fig. 1. Map of the study area (main stem of the Lužická Nisa is between CZ1 and D1). 
The lowlands are dominated by loess. The soils have different properties, particularly with respect to runoff formation, erosion, solute transport and water storage capacity. While soils on mountainous hillslopes are mostly shallow, often skeleton rich dystric cambisols, podzols (Nikodem et al., 2013) and leptosols with high infiltration rate and low storage capacities, the valleys are filled by organosols that release humic and fulvic acids.

Agricultural soils are mostly luvisols and stagnic luvisols with high silt content and low infiltration rate. They are partly affected by poorly drained horizons. Luvisols are easily erodible and contribute to suspended load in the rivers. The lowland flood plains are typically covered by gleysols (Kändler and Seidler, 2009).

Land use differs according to the soil types. While the mountainous areas are dominated by spruce forests and pastures (Pavlů et al., 2007), the fertile soils in the lowlands are agriculturally exploited. Towns and villages in this region are located directly upon the streams. The rivers are linking towns and villages, river beds are often artificially changed and the banks are under revetment. Particularly the agriculturally used loess soils in the lower catchment parts are endangered by surface runoff and erosion, leading to high suspended particle loads and high nutrient concentrations in the rivers (Kändler and Seidler, 2009).

\section{DATA AND METHODS Monitoring}

The long-term hydrometeorological monitoring network in the Lužická Nisa catchment includes five precipitation (Table 1a) monitoring stations (four in the Czech Republic and one in Saxony) and seven runoff (Table 2) gauging stations (four in the Czech Republic and three in Saxony). Precipitation gauges Mlýnice, Chřibská, are operated by the River Labe and River Ohře Authorities respectively. The Liberec station was a temporal station for the purposes of this project and station Bedřichov is operated by the Czech Hydrometeorological
Institute. The Czech runoff gauges are operated by the River Labe Authority (the Uhliŕská gauge is operated by the Czech Technical University in Prague), and the German gauges are operated by the Saxonian Evironmental Authority.

Weekly water samples for determination of ${ }^{18} \mathrm{O} /{ }^{2} \mathrm{H}$ content in rainwater and streamwater were collected in the period from September 2012 until April 2014 typically in weekly mode. They included five (Table 1b) precipitation stations (four in the Czech Republic and one in Saxony), and 38 streamwater (Table 3) profiles (24 in the Czech Republic and 14 in Saxony). Streamwater discrete samples were manually collected into 20 $\mathrm{ml}$ HDPE bottles and stored frozen until the analysis. The streamwater sampling campaign during each week was performed within one day along both the main Lužická Nisa river stem and its tributaries in the Czech Republic and the Mandava River and its tributaries and two stations on the Lužická Nisa River in Germany. The whole catchment was therefore sampled within a few hours. Precipitation was collected in a simple funnel-container device with oil protection of the collected water. In case of snow precipitation, samples were manually collected from the funnel into a closed plastic container and melted. The isotope monitoring in the Uhlířská catchment has been gradually established since 2006, delivering data for studies at catchment (Šanda et al., 2014), hillslope (Dohnal et al., 2006; Dusek et al., 2012) and point (Sněhota et al., 2008) scales.

\section{Laboratory analyses}

The analyses of ${ }^{18} \mathrm{O}$ and ${ }^{2} \mathrm{H}$ were performed at the Czech Technical University in Prague, Faculty of Civil Engineering, using the Liquid Water Isotope Analyzer, LGR Inc. device (Penna et al., 2010). The values are expressed as $\delta^{18} \mathrm{O}, \delta^{2} \mathrm{H}$ in $\%$ of V-SMOW with typical precision of $\delta^{18} \mathrm{O} \pm 0.15 \%$ and $\delta^{2} \mathrm{H}$ $\pm 0.7 \%$ V-SMOW (Vienna Standard Mean Ocean Water).

Contents of ${ }^{18} \mathrm{O}$ and ${ }^{2} \mathrm{H}$ at $\mathrm{CZ17}, \mathrm{CZ24}$, D15 are also analyzed in monthly samples within the framework of the IAEA isotope hydrology databases GNIP and GNIR (Vitvar et al., 2007).

Table 1. Precipitation amount (a-left) and precipitation sampling sites for the water isotopes (b-right).

\begin{tabular}{|l|l|c|c|c|}
\hline Provider & Location & $\begin{array}{c}\text { Altitude } \\
\text { (a.s.1.) }\end{array}$ & $\begin{array}{c}\text { Precipitation } \\
\text { XI/12-X/13 } \\
(\mathrm{mm})\end{array}$ & $\begin{array}{c}\text { Precipitation } \\
\text { 27-Aug-13 to } \\
\text { 4-Sep-13 } \\
\text { (mm) }\end{array}$ \\
\hline CHMI & Bedřichov & 770 & 1613 & 104.0 \\
\hline project & Liberec & 367 & $1119^{*}$ & 37.3 \\
\hline P. Labe & Mlýnice & 390 & 1222 & 51.1 \\
\hline P. Ohre & Chřibská & 440 & 1066 & 31.6 \\
\hline ZÖF Zittau & Zittau & 235 & 965 & 14.0 \\
\hline
\end{tabular}

\begin{tabular}{|l|l|c|c|c|}
\hline Profile & Location & $\begin{array}{c}\text { Altitude } \\
(\text { a.s.1. })\end{array}$ & $\begin{array}{c}27-\text { Aug-13 to } \\
\text { 4-Sep-13 } \\
\left(\mathrm{d}^{18} \mathrm{O}(\%)\right)\end{array}$ & $\begin{array}{c}\text { Amplitude } \\
\mathrm{X} / 12-\mathrm{IV} / 14 \\
\left(\mathrm{~d}^{18} \mathrm{O}(\%)\right)\end{array}$ \\
\hline CZ24 & Uhlírská & 825 & -4.76 & 3.01 \\
\hline CZ25 & Liberec & 367 & -3.76 & 4.16 \\
\hline CZ26 & Oldřichov & 415 & -4.01 & 3.88 \\
\hline CZ50 & Lučany & 565 & -4.37 & 3.78 \\
\hline D15 & Zittau & 235 & -4.66 & 3.23 \\
\hline
\end{tabular}

* correlated with Mlýnice on VII/13-IV/14 data

Table 2. Outflow characteristics of the streams in the catchment.

\begin{tabular}{|l|c|c|c|c|}
\hline Runoff gauge - river / ID & $\begin{array}{c}\text { Altitude } \\
(\text { a.s.l. })\end{array}$ & $\begin{array}{c}\text { Catchment area } \\
\left(\mathrm{km}^{2}\right)\end{array}$ & $\begin{array}{c}\text { Mean outflow XI/12-X/13 } \\
\left(\mathrm{m}^{3} / \mathrm{s}\right)\end{array}$ & $\begin{array}{c}\text { Specific outflow XI/12-X/13 } \\
\left(\mathrm{m}^{3} / \mathrm{s} / \mathrm{km}^{2}\right)\end{array}$ \\
\hline Uhliřská - Černá Nisa / CZ17 & 792 & 1.2 & 0.05 & 41.0 \\
\hline Proseč - Lužická Nisa / CZ4 & 401 & 53.7 & 1.42 & 26.4 \\
\hline Mníšek - Jeřice / CZ9 & 375 & 32.2 & 0.35 & 10.9 \\
\hline Varnsdorf - Mandava / above D4 & 314 & 88.9 & 1.53 & 17.2 \\
\hline Zittau - Mandava / D3 & 239 & 293.9 & 3.68 & 12.5 \\
\hline Hartau - Lužická Nisa / (CZ16-D2) & 241 & 377.5 & 7.12 & 18.9 \\
\hline Zittau - Lužická Nisa / D1 & 235 & 694.0 & 11.85 & 17.1 \\
\hline
\end{tabular}


Pre-event water contributions and streamwater residence times in different land use settings

Table 3. List of streamwater sampling sites, land use characteristics and results of the analyses utilizing stable isotopes in streams in the Lužická Nisa catchment „wtp” abbreviates water treatment plant in Liberec. "Lake” denotes the catchment of the artificial lake Olbersdorfer See. "Urban" denotes small catchments entirely located in developed zones and drained through artificially designed channels or pipes. Landuse categories: Forest-more than $90 \%$ of non-urban areas, with a dominant forest component greater than the sum of urban land and arable land and grassland; Agriculture-more than $80 \%$ of non-urban areas, with a prevailing arable land and grassland component; Urbanbelow $80 \%$ of non-urban areas; Mix-mixed category of more than $80 \%$ of non-urban land with prevailing forest, but not dominant (greater than the sum of other components).

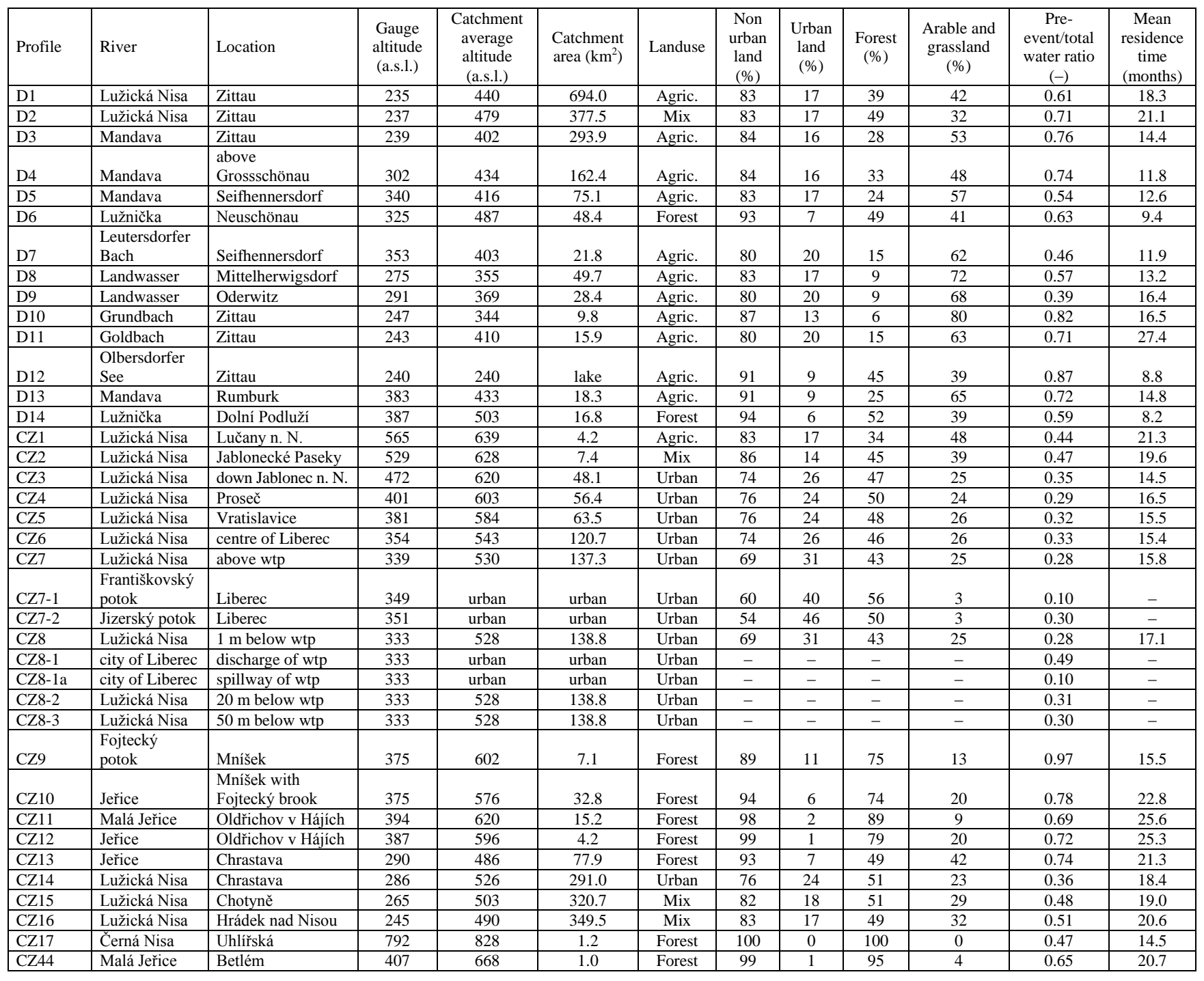

\section{Data interpretation}

Isotopic separation of event and pre-event water was based on the mixing equation

$R_{s}=\frac{Q_{s}}{Q_{t}}=\frac{c_{t}-c_{n}}{c_{s}-c_{n}}$

where $Q_{t}-$ total (event \& pre-event) flow $\left(\mathrm{m}^{3} / \mathrm{s}\right), Q_{s}$ - pre-event flow fraction $\left(\mathrm{m}^{3} / \mathrm{s}\right)(\% \mathrm{~V}-\mathrm{SMOW}), c_{t}-{ }^{18} \mathrm{O}$ content in the streamwater, $c_{s}-{ }^{18} \mathrm{O}$ content in the pre-event baseflow (\%o $\mathrm{V}$ SMOW), $c_{n}-{ }^{18} \mathrm{O}$ content in the rainwater during the event (\%o V-SMOW), and $R_{s}$ - volumetric ratio of the pre-event water in the total outflow.

The calculation was performed for the 38 studied gauges at the peakflow September 3, 2013, using the average and standard deviation of ${ }^{18} \mathrm{O}$ content $\left(c_{n}\right)$ in precipitation of five sampled stations (Uhlířská, Liberec, Oldřichov, Lučany, Zittau) during the period August 27- September 3, 2013 (see Table 1 for details). The $c_{s}$ values are equal to the ${ }^{18} \mathrm{O}$ content in streamwater at each of 38 profiles on August 24, 2013 - the last sampling, considered as baseflow before the event.

\section{Water residence times}

Streamflow residence times were estimated using the seasonal sine-wave variations of $\delta^{18} \mathrm{O}$ in monthly step in the streamflow and cumulative precipitation (Kralik, 2015). The seasonal variations in $\delta^{18} \mathrm{O}$ are expressed (Eq. 2)

$$
\delta^{18} \mathrm{O}=\operatorname{mean}\left(\delta^{18} \mathrm{O}\right)+A \sin [(2 \pi t / b)+c]
$$

where mean $\left(\delta^{18} \mathrm{O}\right)\left(\% \mathrm{~V}\right.$-SMOW) is the mean value of $\delta^{18} \mathrm{O}, A$ (\%o V-SMOW) is the seasonal amplitude of $\delta^{18} \mathrm{O}, b$ is the period of a seasonal cycle (one-year period is $2 \pi$ ), $t$ is time 
(months), and $c(\mathrm{rad})$ is the phase shift. Parameters mean $\left(\delta^{18} \mathrm{O}\right)$, $A$ and $c$ were obtained by fitting Eq. (2) on the experimental data via least squares optimization. Mean residence time (MRT) is reflected in the decrease of the input amplitude in precipitation $\left(A_{p}\right)$ relative to the output amplitude (e.g. in streamflow A) in the linear reservoir, according to Eq. (3).

$M R T=\left(\frac{1}{b}\right)\left[\left(\frac{A_{p}}{A}\right)^{2}-1\right]^{0.5}$

where $(1 / b)=12 / 2 \pi$ is the factor for the residence time in months.

This fitting was performed for the $\delta^{18} \mathrm{O}$ values at all five precipitation sampling stations Uhlířská, Liberec, Oldřichov, Lučany, Zittau (cumulative weekly samples) and the stream (grab weekly samples) at the studied 38 profiles for the period October 2012-April 2014. The variability of $A_{p}$ (expressed as average and standard deviation of each of the five precipitation stations) is therefore caused by the different amplitudes of $\delta^{18} \mathrm{O}$ values at the respective five rainfall stations (see Table 1).

The coefficient of determination $\mathrm{R}^{2}$ expresses the linear least square determination.

\section{RESULTS AND DISCUSSION Monitoring}

Fig. 2 shows selected hydroclimatical and isotopic characteristics of precipitation and streamwater for the period September 2012-April 2014. It displays daily temperature and precipitation amount at the wettest station Bedrrichov, daily discharge at headwaters of the Lužická Nisa (CZ17), catchment outlet (D1) and main tributary (D3), weekly ${ }^{18} \mathrm{O}$ content in precipitation at the five sampling stations (see also Tab. 1b), and weekly ${ }^{18} \mathrm{O}$ content in streamwater at seven selected profiles. No significant gradients in isotopic composition of precipitation were observed, indicating a homogeneous origin of precipitation over the study area. Very similar ${ }^{18} \mathrm{O}$ patterns in streams are observed during winter and early spring. The ${ }^{18} \mathrm{O}$ depleted streamwater of the mountain headwaters occurs only along the main Lužická Nisa stem and its tributaries in the Czech Republic and sustains during summer and autumn in particular. In contrast, streamwater in the the Mandava and Lužnička (D3 and D6) follow patterns of elevated ${ }^{18} \mathrm{O}$, due to non-existing impact of mountainous headwaters. These overall patterns were biased by the isotopically distinct rainfall-runoff event in September 2013.

The ${ }^{18} \mathrm{O}$ content in streamwaters at all 38 monitoring profiles is shown in Fig. 3 (top panel). The main stream of the Lužická Nisa (15 profiles from CZ1 to D1) shows a gradual increase of $\delta^{18} \mathrm{O}$ values and decrease of their variations along with the progressing mixing towards the catchment outlet. The median $\delta^{18} \mathrm{O}$ values along the main stem of Lužická Nisa reach from -10 to $-9.5 \%$ V-SMOW, which corresponds to the median $\delta^{18} \mathrm{O}$ values in precipitation (Fig. 2). The profiles CZ17 (Černá Nisa) and CZ9-13, CZ44 (Jeřice) represent mountainous headwaters from the Jizera Mountains with depleted $\delta^{18} \mathrm{O}$ values. Streams at the profiles CZ7-1 and CZ7-2 (Františkovský and Jizerský brooks, resp.) drain entirely developed city areas, and the profiles CZ8-1 and CZ8-1a are outlet and spillway of the city water treatment plant. The $\delta^{18} \mathrm{O}$ values at these four profiles are therefore highly affected by human impact. Profiles D13, D5, D4 and D3 represent the Mandava River with no major impact of mountainous headwaters. Impact of the
Lužické Mountains is observed in the Mandava tributary Lužnička (D6, D14) in more depleted $\delta^{18} \mathrm{O}$ values compared to profiles in their vicinity (D8, D9). The lowland tributary Landwasser coming from northwest (D9, D8) has no impact of mountains. The Mandava tributaries Grundbach (D10) and Goldbach (D11) drain the area of the Lusatian fault where possible impact of groundwater circulation with particular isotopic composition and smaller isotopic variations may be hypothesized. Finally, D12 represents the outlet of the Olbersdorfer See (lake) with associated evaporative effects on the ${ }^{18} \mathrm{O}$ content.

\section{Isotopic separation of pre-event water and calculation of water residence times}

Isotopic separation of event and pre-event water (Fig. 4a) was performed for the peakflow on September $3^{\text {rd }}, 2013$ with causal pre-event rainfall during August 27-September 4, 2013. This event has occured after three weeks with no precipitation and caused a discharge rise at all studied profiles. It is hypothesized (Fig. 4b) that the minor precipitation amounts on August 28 and September 1 contributed to the increase of the antecedent moisture, causing a major streamflow peak on September 3.

This event was characterized by particularly enriched $\delta^{18} \mathrm{O}$ values in the causal pre-event rainfall (Table 1b), reaching from $-3.76 \%$ V-SMOW at Liberec to $-4.76 \%$ V-SMOW at Uhlírská, with average $-4.13 \%$ V-SMOW and standard deviation $0.41 \%$ V-SMOW. $\delta^{18} \mathrm{O}$ values in streamwater at the peakflow (September $3^{\text {rd }}, 2013$ ) reached up to $-5.8 \%$ V-SMOW from the background of -10.0 to $-8.5 \%$ V-SMOW (Figs. 4cd).

Fig. 5 and Table 3 display the calculated ratio of pre-event water (Eq. 1). The highest portions of the pre-event water were identified in two catchments CZ9 and D12, affected by the lakes Fojtka and Olbersdorfer, respectively. It is hypothesized that older water was released from the lakes during the stormflow event, causing a higher portion of the pre-event water. High portions of the pre-event water appeared also in the nearly natural Jeřice (CZ10-CZ13, C44) subcatchment, covered dominantly by forests and meadows, and with little or no impact of settlements. The source of elevated pre-event water portions at D10 and D11 may include groundwater inflow along the Lusatian fault. More than $70 \%$ of the total runoff has pre-event origin in the Mandava catchment (D13, D11, D4 and D3). The main stem of the Lužická Nisa River (CZ1-D1) ranges from $69 \%$ to $79 \%$ of pre-event water, with lower values in the agglomerations (CZ4, CZ7). The Leutersdorfer brook (D7) and the Landwasser (D8, D9) were drained by $46 \%, 57 \%$ and $39 \%$ of pre-event water, respectively. Lowest values of $R_{s}$ were identified at the profile CZ8-1a (10\%) discharging from the water treatment plant. It can be hypothesized that the dominant rainfall amount prior to the event at Bedřichov (Table 1a) resulted in significant portions of event water along the Lužická Nisa main stem, whereas the smaller causal rainfall amounts in the western lowland part of the catchment (Zittau) resulted in a less pronounced rapid runoff in the Mandava catchment.

Five calculations of mean residence times using sine-wave amplitudes of five rainfall stations were carried out for each streamflow gauge (Tab. 1b). The average amplitude of $\delta^{18} \mathrm{O}$ values in precipitation at the five sampling stations in the period October 2012-April 2014 was 3.61\%o V-SMOW with a standard deviation of $0.47 \%$ V-SMOW.

The highest mean residence time of streamwater (25-27 months) were estimated in the nearly natural Jerrice (CZ11, CZ12) and in the Goldbach (D11) catchments (Table 3). 


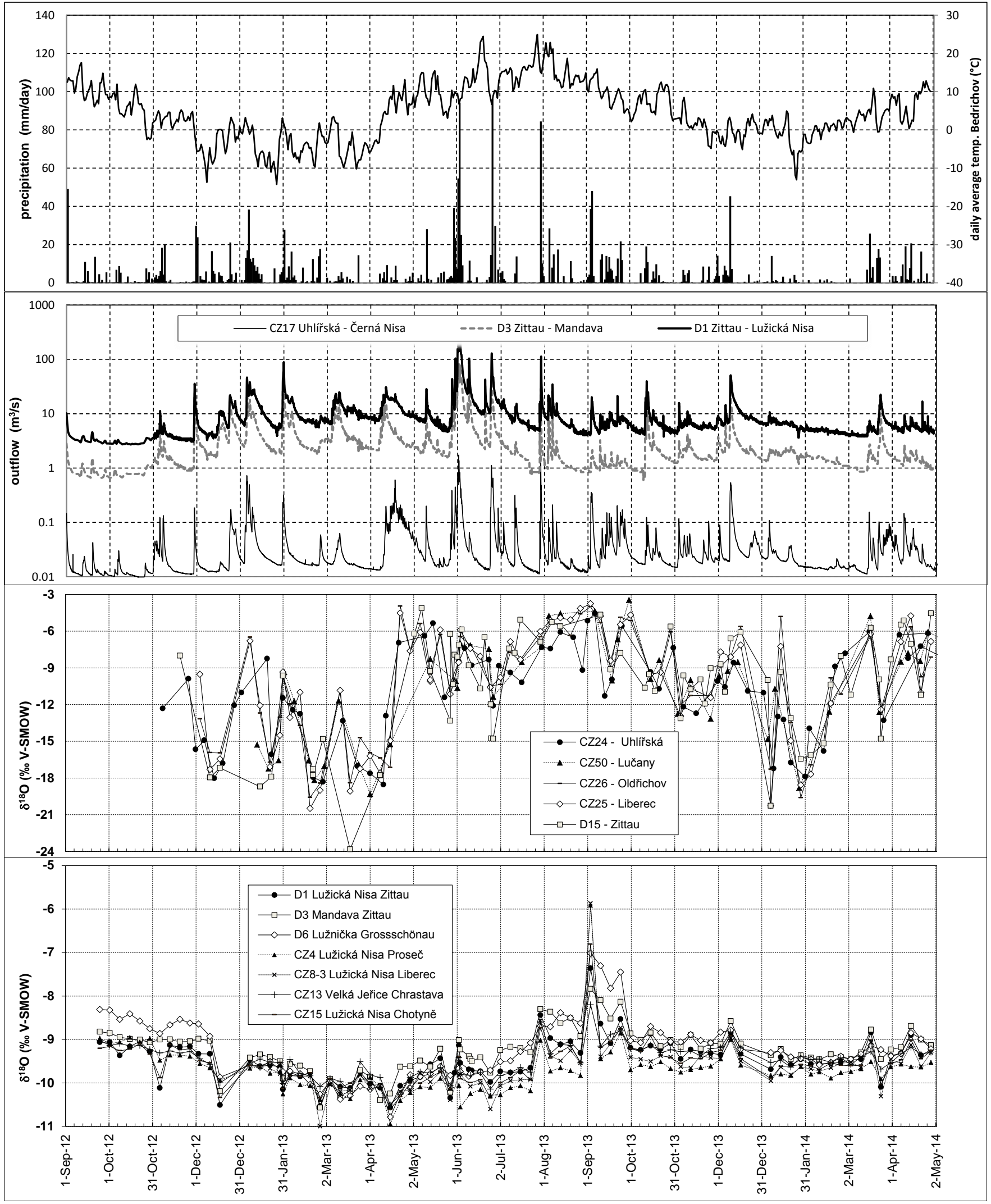

Fig. 2a, b, c, d (top to bottom). a) Air temperature and daily precipitation at the Bedríchov station, b) streamflow and c) $\delta{ }^{18} \mathrm{O}$ content in precipitation and d) in streamwater at selected profiles, for the period September 2012 - April 2014.

The latter may be associated with deeper groundwater contribution along the Lusatian fault. The main stream of the Lužická Nisa shows streamwater residence times between 15 and 20 months (with lowest values in the agglomeration CZ3-CZ7) and the Mandava (D13, D5, D4, D3), Grundbach (D10) and
Landwasser (D8, D9) between 10 and 16 months. The relatively shorter streamwater residence times in the lowland Mandava catchment and its tributaries may be attributed to river terraces and alluvia. Therefore, the bulk of the river water probably comes from areas which are relatively close to the river, resulting 

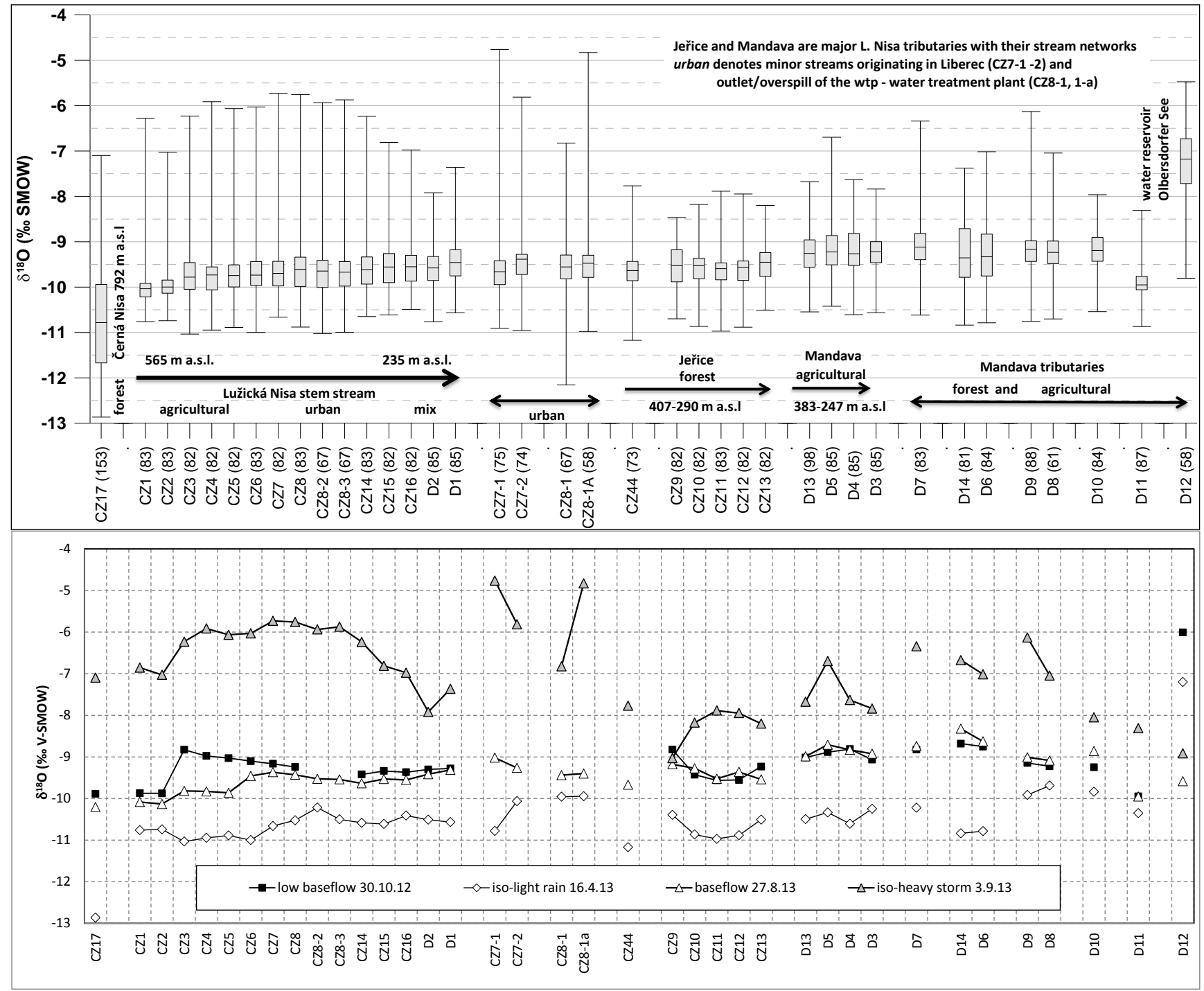

Fig. 3a, b (top to bottom). $\delta{ }^{18} \mathrm{O}$ in streamwaters along the principal water courses and their tributaries (number of collected samples in brackets). a) Box-Whisker-Plots for the period September 2012 - April 2014. b) Evolution of $\delta^{18} \mathrm{O}$ along the river network in selected hydrological situations (light isotopic rain, pre-event baseflow, heavy isotopic storm, and typical baseflow).

in shorter mean residence times (Dóša et al., 2011). The shortest residence times were identified in the Lužnička catchment (D9 and D14) with very shallow aquifer. Residence time was not calculated for the channelled streams CZ7-1and CZ7-2 and the overflow and spillway from the water treatment plant CZ81 and CZ8-1a.

Similarly to several previous studies on mesoscale nested catchments (Soulsby et al., 2010; Tetzlaff et al., 2007), the mean streamwater residence times in the Lužická Nisa catchment reveal no significant correlation with the catchment altitude and area (Figs. 6a, b). In contrast, the pre-event water portion $\mathrm{R}_{\mathrm{s}}$ increases with the catchment area (Fig. 6c). This supports the hypothesis that larger rivers have larger portion of pre-event water from river banks and alluvium. This portion, however, do not always imply longer streamwater residence time in the lowland subcatchments, because the groundwater discharge from lowland river banks is often younger than contributions from deeper fractures in the granitic headwaters. For example, Dóša et al. (2011) used $\delta^{18} \mathrm{O}$ in the sine-wave method and reported a shorter mean residence time in streamwater of the Váh River below the Slovak Tatra Mountains (13 months) than in the headwaters Jalovecký potok Creek (19 months). Similarly, Soulsby et al. (2010) reported a shorter mean residence time of the Scottish streamwater Upper Dee (600 days) than in its headwaters (more than 2 years). In contrast, Capell et al. $(2011,2012)$ have found a largely muted response of stable isotopes in lowland streamwater in the 749$\mathrm{km}^{2}$ large mesoscale catchment North Eck in Scotland (very similar catchment size of $687 \mathrm{~km}^{2}$ to the Lužická Nisa). They have ascribed this result to the strong differences in geological and soil conditions between the lowland catchments and headwaters, which causes a strong dumping of the tracer input. According to Fig. 2d, however, this phenomemon is not observed in the Lužická Nisa catchment. All profiles along the main Lužická Nisa stem and the lowland Mandava tributary reveal similar annual variations of $\delta^{18} \mathrm{O}$ of around $3 \% \mathrm{~V}$ SMOW (excluding the event from September 2013). During autumn baseflow periods, the entire course of the Lužická Nisa carries isotopically depleted waters, originating in the mountainous wetlands with dominantly snowmelt-induced recharge (Šanda et al., 2014). We argue that the pronounced isotopic variability of streamwaters throughout the entire Lužická Nisa catchment is caused by relatively shallow aquifers in the dominantly Neogene Zittau basin, which precludes development of deeper aquifers. 


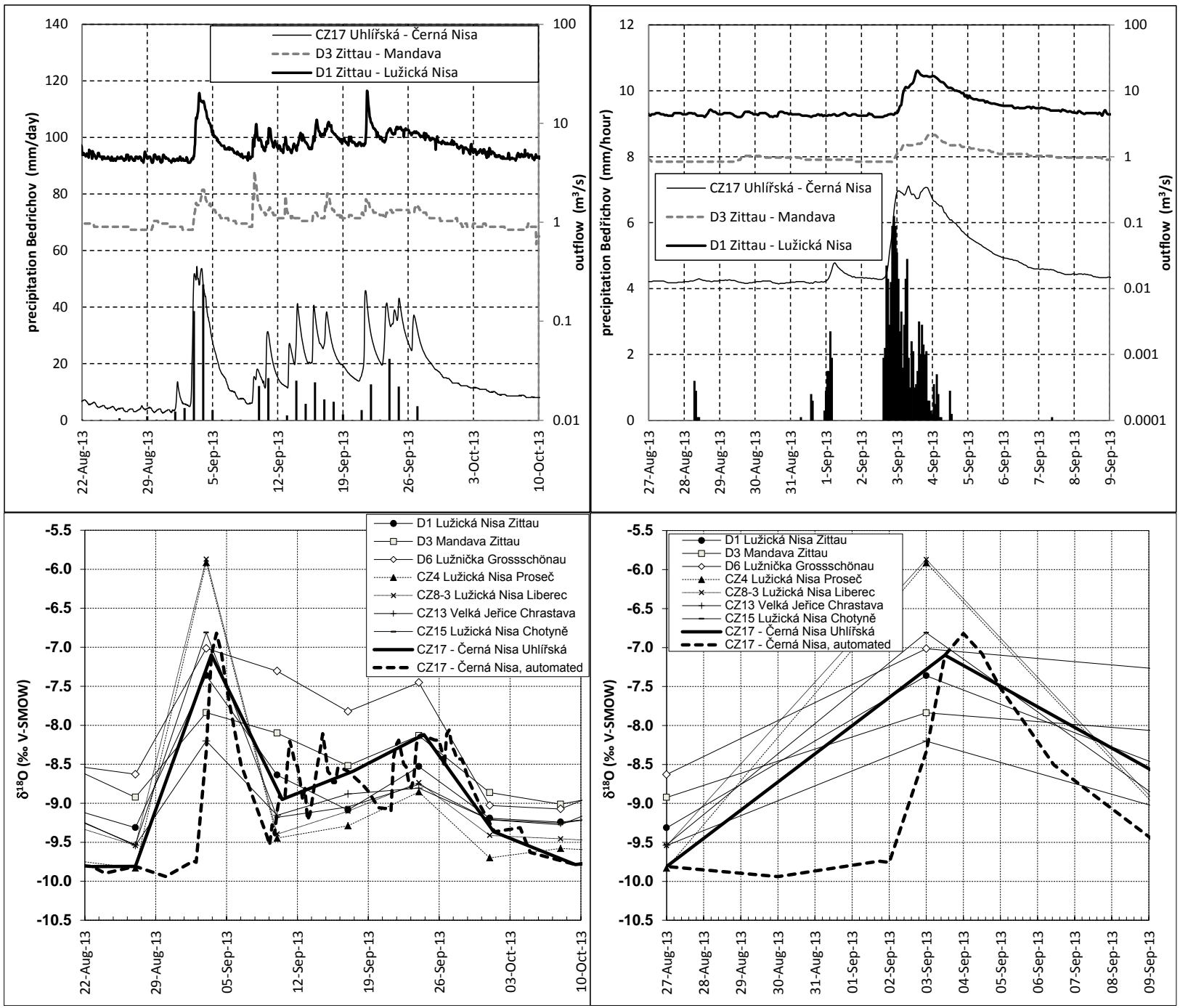

Fig. 4a, b, c, d (top left to bottom right). Rainfall-runoff episode used for isotopic separation of the peakflow of September 3, 2013. a) Precipitation and discharge during the entire episode August 22- October 10, b) Detailed record during the peakflow period August 27September 9 , c) $\delta{ }^{18} \mathrm{O}$ in streamflow during the entire episode August 22- October 10 , and d) $\delta^{18} \mathrm{O}$ in streamflow during the peakflow period August 27-September 9, showing the response of the catchments on the storm event with significantly different isotopic content . Bold lines for CZ17 headwater catchment Uhlírská indicate manual weekly and automated (daily or 4x daily sampling at the only station of the network), showing relatively good capture of the event by weekly sampling, including the peakflow.

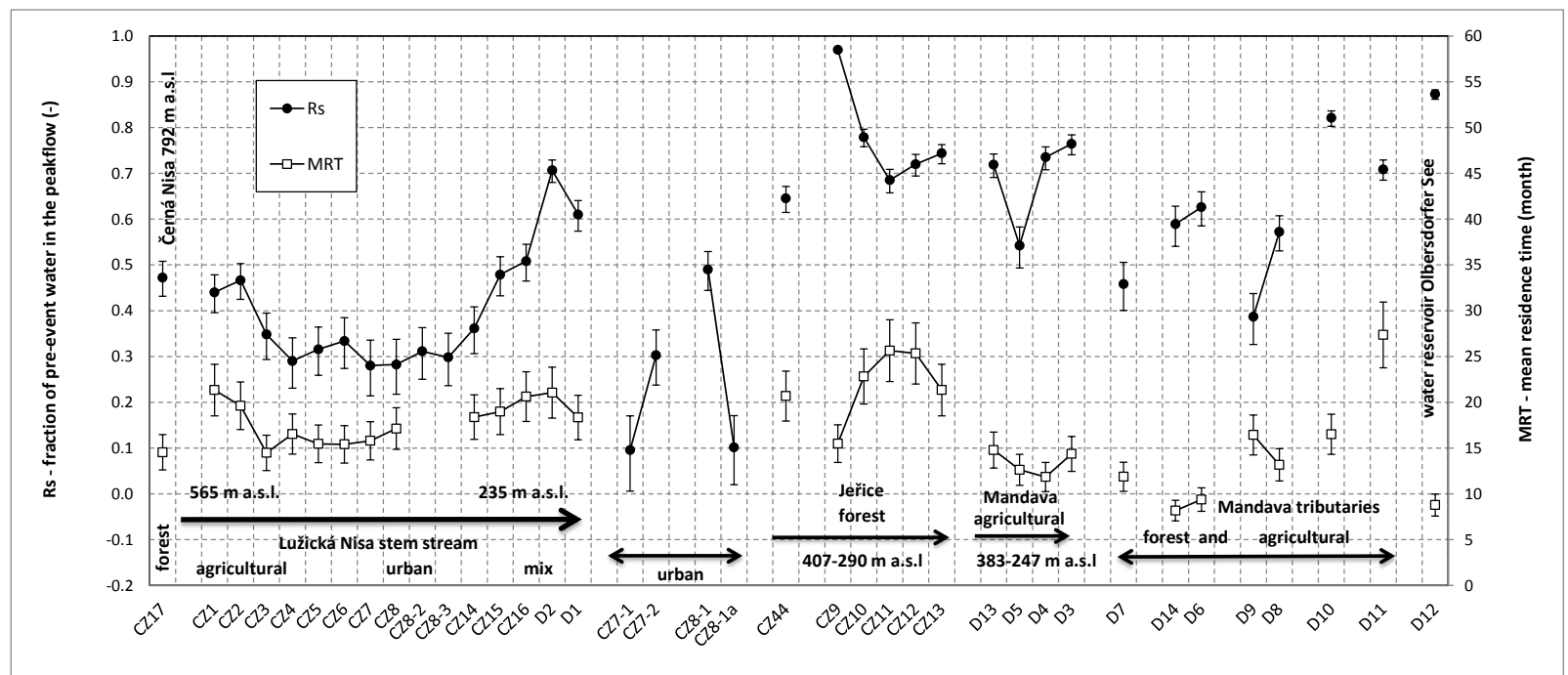

Fig. 5. Volumetric ratio of pre-event water in the peakflow during the event on September 32013 based on ${ }^{18} \mathrm{O}$ isotopic separation and mean residence time (MRT) of the streamwaters. The error bars show the variability of the results calculated using different ${ }^{18} \mathrm{O}$ contents in the causal rainfall at the five sampling stations. 

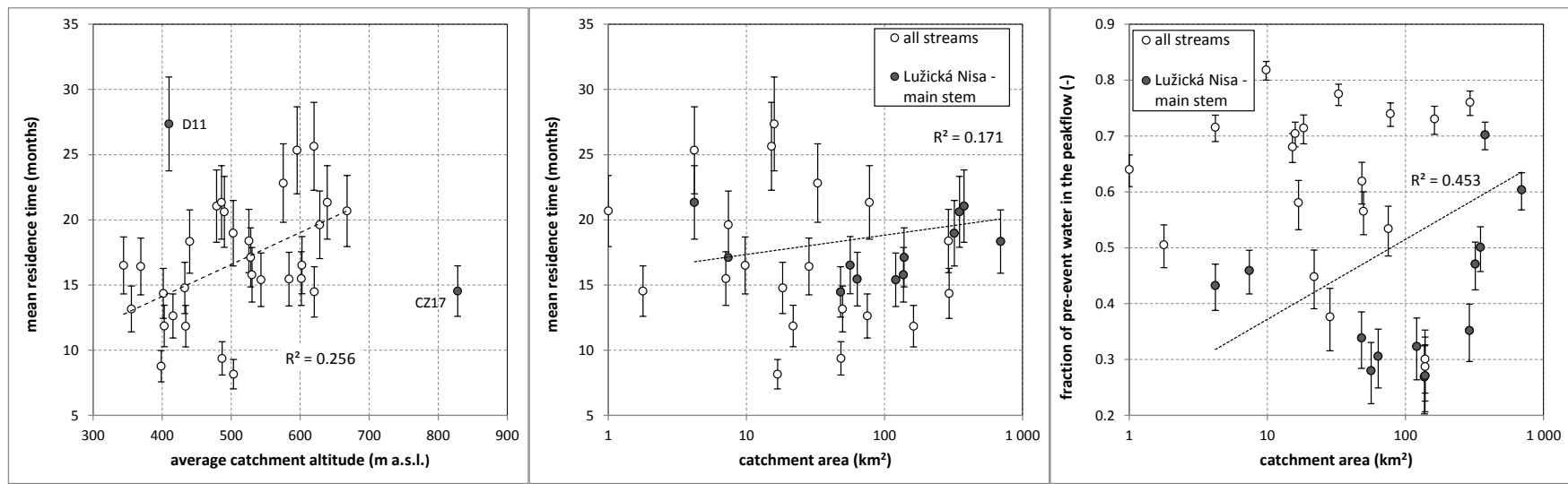

Fig. 6a, b, c. Three examples of relationships between altitude, area, mean residence time and fraction of pre-event water (for Lužická Nisa - main stem, when applicable). The error bars for the pre-event water fraction show the variability of the results calculated using different ${ }^{18} \mathrm{O}$ contents in the causal rainfall at the five sampling stations. The error bars for the mean residence times show the variability of residence time calculations using different amplitudes of ${ }^{18} \mathrm{O}$ contents in precipitation at the respective five rainfall stations.

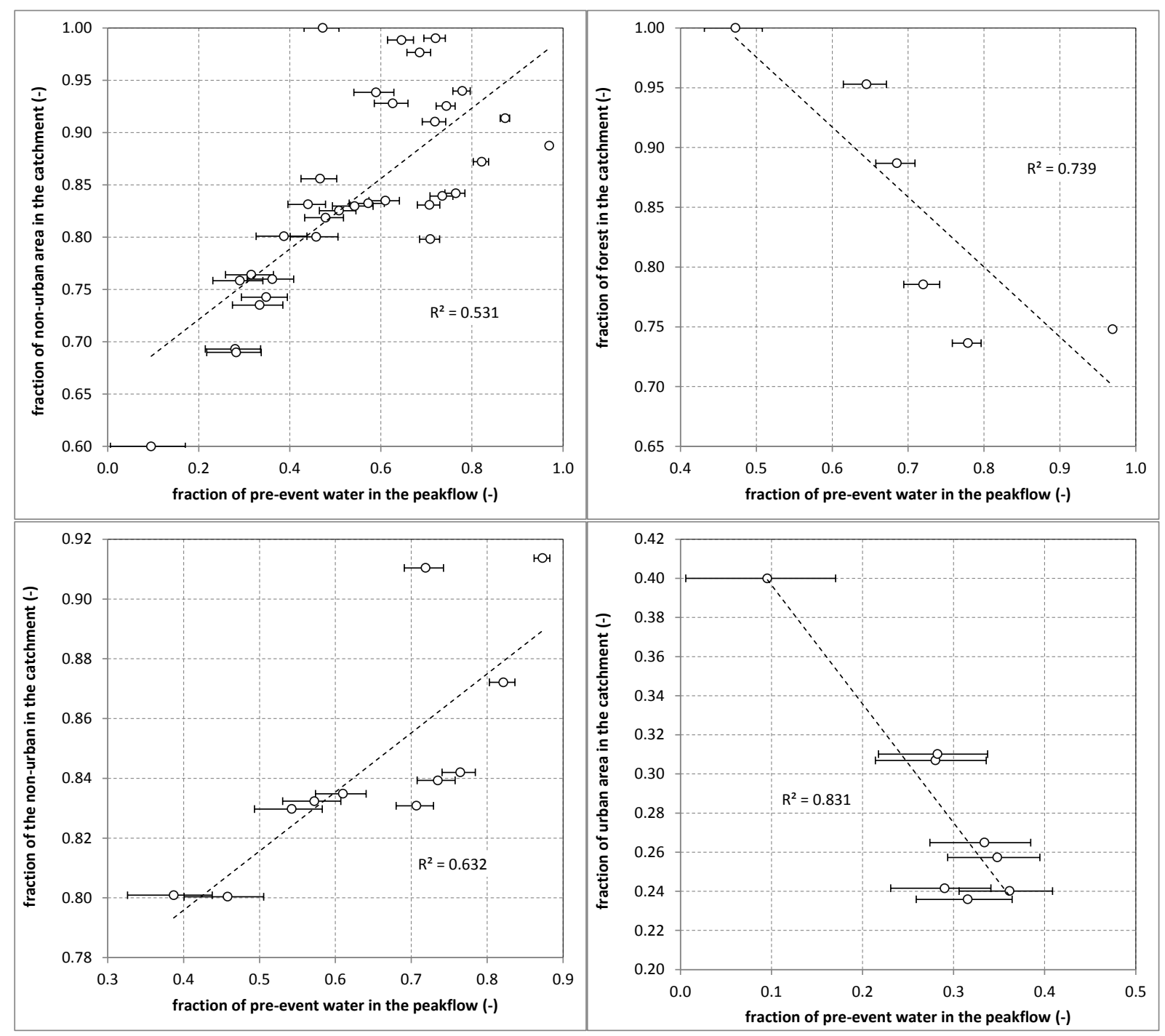

Fig. 7a, b, c, d. Relationship of fraction of pre-event water and landuse. All nested catchments (a-top left), small forested Czech catchments, category I (b-top right), agricultural catchments, mostly German, category II (c-bottom left), most urbanized Czech catchments Jablonec n.N, Liberec, Chrastava , category III (d-bottom right). The landuse categories I, II and III are defined in Table 3 . The error bars for the pre-event water fraction show the variability of the results calculated using different ${ }^{18} \mathrm{O}$ contents in the causal rainfall at the five sampling stations. 
Fig. 7 shows the relationship between landuse (Table 3) and the pre-event water fraction. Fig. 7a shows a weak overall increase of the pre-event water fraction with increasing portion of non-urban landuse in the respective catchment, where nonurban is understood as sum of forest, arable land, grassland, orchards and open water. Three distinct categories evolve upon distribution of catchments according to the degree of non-urban landuse (Table 3). The category "Forest" of 90-100\% nonurban landuse contains all Czech mountainous headwaters CZ10-CZ13, CZ17 and CZ44 (Fig 7b), with a dominant portion of forest which is greater than the sum of urban land, arable land and grassland. The fraction of pre-event water in this group decreases with the percentage of forest, revealing that forests may provide only a limited infiltration of precipitation due to leaf interception and soil water use for transpiration (Nadezhdina et al., 2010). Not included in this assessment are the Lužnička stream profiles D6 and D14. Despite the low degree of urban landuse, these catchments have only a shallow aquifer that does not allow for storage of and mixing with preevent water. The category "Agriculture" of $80-90 \%$ of nonurban landuse dominantly contains the Mandava, Landwasser and Leutersdorfer Bach subcatchments, with prevailing arable and grassland. In this group, the fraction of pre-event water is directly related to the non-urban landuse degree (Fig. 7c). The category "Urban" contains most developed catchments below $80 \%$ of non-urban land. In this group the increasing fraction of pre-event water is accompanied by a decrease of the percentage of urban landuse. Other catchments ("Mix") that contain more than $80 \%$ of non-urban land, but no dominant forest component such as in category "Forest", are not included in Fig. 7. They are considered as mixed-landuse catchments.

\section{CONCLUSIONS}

The study presents a readily available approach of an assessment how individual subcatchments contribute to the hydrological response of a larger mesoscale catchment with highly heterogeneous land use and landscape characteristics. It improves the understanding of the role of topography, geology and land use with respect to origin, mixing and residence time of water in the subcatchments. The study also shows the variability of calculated residence times and pre-event water fractions, caused by the uncertainty and heterogeneity of the isotopic rainfall input to the catchment. Although the approach is based on the standard two-component mixing techniques, it provides a comparison of heterogeneous settings that cannot be assessed using techniques at hillslopes or headwater scales. Unlike several previous studies conducted typically in less developed catchments, the Lužická Nisa catchment includes a large variety of landscapes to explore phenomena such as the impact of urbanization on baseflow and its contributions to peak event flow or impact of the lowland alluvial riparian zone on the streamwater residence times. This assessment may be used in both gauged and ungauged mesoscale basins.

Acknowledgement. The research was funded by the Czech Science Foundation, project No. 14-15201J and by EU programme Ziel3/Cíl3, No. 100114993 and student grant of CTU SGS16/143/OHK1/2T/11. Authors thank Labe River Authority and Ohře River Authority for hydrological data provision.

\section{REFERENCES}

Alfieri, L., Salamon, P., Bianchi, A., Neal, J., Bates, P., Feyen, L., 2014. Advances in pan-European flood hazard mapping.
Hydrol. Proc., 28, 4067-4077.

Bissolli, P., Friedrich, K., Rapp, J., Ziese, M., 2011. Flooding in eastern central Europe in May 2010 - reasons, evolution and climatological assessment. Weather, 66, 147-153.

Capell, R., Tetzlaff, D., Malcolm, I.A., Hartley, A.J., Soulsby, C., 2011. Using hydrochemical tracers to conceptualise hydrological function in a large scale catchment draining contrasting geologic provinces. J. Hydrol., 408, 164-177.

Capell, R., Tetzlaff, D., Soulsby, C., 2012. Can time domain and source area tracers reduce uncertainty in rainfall runoff models in larger heterogeneous catchments? Water Resour. Res., 48, W09544.

Dohnal, M., Dušek, J., Vogel, T., 2006. The impact of the retention curve hysteresis on prediction of soil water dynamics. J. Hydrol. Hydromech., 54, 258-268.

Dóša, M., Holko, L., Kostka, Z., 2011. Estimation of the mean transit times using isotopes and hydrograph recessions. Die Bodenkultur, 62, 47-52.

Dusek, J., Vogel, T., Dohnal, M., Gerke, H.H., 2012. Combining dual-continuum approach with diffusion wave model to include a preferential flow component in hillslope scale modeling of shallow subsurface runoff. Adv. Water Res., 44, 113-125.

Dutton, A., Wilkinson, B.H., Welker, J.M., Bowen, G.J., Lohmann, K.C., 2005. Spatial distribution and seasonal variation in $18 \mathrm{O} / 16 \mathrm{O}$ of modern precipitation and river water across the conterminous United States. Hydrol. Process., 19, 4121-4146.

Farský, I., 1992. A comment on the anthropogenic impacts at the upper flow of the river Lužická Nisa. Sborník čes. geogr. spol., 97, 26-32.

Herczeg, A.L., Leaney, F.W., 2011. Review: environmental tracers in arid-zone hydrology. Hydrogeol. J., 19, 17-29.

Holko, L., Kostka, Z., Šanda, M., 2011. Assessment of Frequency and Areal Extent of Overland Flow Generation in a Forested Mountain Catchment. Soil \& Water Res., 6, 1, 43-53.

Isik, S., Kalin, L., Schoonover, J.E., Srivastava, P., Lockaby, G.B., 2013. Modeling effects of changing land use/cover on daily streamflow: An artificial neural network and curve number based hybrid approach. J. Hydrol., 485, 103-112.

Kändler, M., Seidler, C., 2009. Hydrochemical Load in a Small River Following Heavy Rain Events. Folia Geographica, Series Geographica-Physica, 40, 27-32.

Kendall, C., Coplen, T.B., 2001. Distribution of oxygen-18 and deuterium in river waters across the United States. Hydrol. Process., 15, 1363-1393.

Klaus, J., McDonnell, J.J., 2013. Hydrograph separation using stable isotopes: review and evaluation. J. Hydrol., 505, 47-64.

Klomínský, J., 1969. The Krkonoše-Jizera granitoid massif. Sb. geol. věd, 15, 1-134.

Köplin, N., Viviroli, D., Schädler, B., Weingartner, R., 2014. How does climate change affect mesoscale catchments in Switzerland? - A framework for a comprehensive assessment. Adv. Geosci., 27, 111-119.

Kralik, M., 2015. How to estimate mean residence times of groundwater. Proc. Earth Planet. Sci., 13, 301-306.

Markovics, R., Kanduč, T., Szramek, K., Golobočanin, D., Milačič, R., Ogrinc, N., 2010. Chemical dynamics of the Sava riverine system. J. Eviron. Monit., 12, 2165-2176.

McDonnell, J.J., McGuire, K., Aggarwal, P., Beven, K.J., Biondi, D.,Destouni, G., Dunn, S., James, A., Kirchner, J., Kraft, P., Lyon, S., Maloszewski, P., Newman, B., Pfister, L., Rinaldo, A., Rodhe, A., Sayama, T., Seibert, J., Solomon, K., Soulsby, C., Stewart, M., Tetzlaff, D., Tobin, C., Troch, P., Weiler, M., Western, A., Wörman, A., Wrede, S., 2010. 
How old is streamwater? Open questions in catchment transit time conceptualization, modelling and analysis. Hydrol. Process., 24, 1745-1754.

McGuire, K.J., McDonnell, J.J., Weiler, M., Kendall, C., McGlynn, B.L., Welker, J.M., Seibert, J., 2005. The role of topography on catchment scale water residence time. Water Resour. Res., 41, 1-14.

Montzka, C., Kanty, M., Kunkel, R., Menz, G., Vereecken, H.,Wendland, F., 2008. Modelling the water balance of a mesoscale catchment basin using remotely sensed land cover data. J. Hydrol., 353, 322-334.

Nadezhdina, N., $\quad$ David, T.S., $\quad$ David, J.S., $\quad$ Ferreira, M.I., Dohnal, M., Tesař, M., Gartner, K., Leitgeb, E., Nadezhdin, V., Čermák, J., Jimenez, M.S., Morales, D., 2010. Trees never rest: the multiple facets of hydraulic redistribution. Ecohydrol., 3, 431-444.

Niehoff, D., Fritsch, U., Bronstert, A., 2002. Land-use impacts on storm-runoff generation: Scenarios of land-use change and simulation of hydrological response in a meso-scale catchment in SW-Germany. J. Hydrol., 267, 80-93.

Nikodem, A., Kodešová, R., Bubeníčková, L., 2013. Simulation of the influence of rainfall redistribution in spruce and beech forest on the leaching of $\mathrm{Al}$ and $\mathrm{SO}_{4}{ }^{2-}$ from forest soils. J. Hydrol. Hydromech., 61, 39-49.

Pardo, L.H., Kendall, C., PettRidge, J., Chang, C.C.Y., 2004. Evaluating the source of streamwater nitrate using d $15 \mathrm{~N}$ and $\mathrm{d} 18 \mathrm{O}$ in nitrate in two watersheds in New Hampshire, USA. Hydrol. Process., 18, 2, 699-712.

Pavlů, V., Hejcman, M., Pavlů, L., Gaisler, J., 2007. Restoration of grazing management and its effect on vegetation in an upland grassland. Appl. Veget. Sci., 10, 375-382.

Pawellek, F., Frauenstein, F., Veizer, J., 2002. Hydrochemistry and isotope geochemistry of the upper Danube River. J. Hydrol., 66, 3839-3853.

Penna, D., Stenni, B., Šanda, M., Wrede, S., Bogaard, T.A., Gobbi, A., Borga, M., Fischer, B.M.C., Bonazza, M., Chá- rová, Z., 2010. On the reproducibility and repeatability of laser absorption spectroscopy measurements for $\delta^{2} \mathrm{H}$ and $\delta^{18} \mathrm{O}$ isotopic analysis. Hydrol. Earth Syst. Sci., 14, 1551-1566.

Pohle, I., Koch, H., Conradt, T., Gädeke, A., Grünewald, U., 2015. Potential impacts of climate change and regional anthropogenic activities in Central European mesoscale catchments. Hydr. Sci. J., 60, 912-928.

Popescu, R., Costinel, D., Ionete, R.E., Axente, D., 2014. Isotopic fingerprint of the middle Olt River basin, Romania. Isotopes Eviron. Health Stud., 50, 461-474.

Šanda, M., Vitvar, T., Kulasová, A., Jankovec, J., Císlerová, M., 2014. Runoff formation in a humid, temperate headwater catchment using a combined hydrological, hydrochemical and isotopic approach Jizera Mountains, Czech Republic. Hydrol. Process., 28, 3217-3229.

Sněhota, M., Sobotková, M., Císlerová, M., 2008. Impact of the entrapped air on water flow and solute transport in heterogeneous soil: experimental set-up. J. Hydrol. Hydromech., 56, 247-256.

Soulsby, C., Tetzlaff, D., Hrachowitz, M., 2010. Spatial distribution of transit times in montane catchments: conceptualization tools for management. Hydrol. Process., 24, 32833288.

Tetzlaff, D., Waldron, S., Brewer, D.J., Soulsby, C., 2007. Assessing nested hydrological and hydrochemical behaviour of a mesoscale catchment using continuous tracer data. J. Hydrol., 336, 430-443.

Uhlenbrook, S., Roser, S., Tilch, N., 2004. Hydrological process representation at the meso-scale: the potential of a distributed, conceptual catchment model. J. Hydrol., 291, 278-296.

Vitvar, T., Aggarwal, P.K., Herczeg, A.L., 2007. Global network is launched to monitor isotopes in rivers. EOS, Trans. AGU, 88, 325-326.

Received 5 May 2016 Accepted 14 October 2016 